\title{
Withdrawal Note: Expression of Ski in the Follicles of eCG-primed Immature Hypophysectomized Rat Ovary
}

Yeoung-Gyu Ko ${ }^{2}$, Dong Hun Kim², Soo Bong Park², Sung Woo Kim², Yoon Jung Do ${ }^{2}$ and Hyun Kim ${ }^{1,2^{*}}$

\section{Retraction}

This article [1] has been retracted by the corresponding author, Hyun Kim, because the data reported in the article have been previously published the Journal of Reproduction and Development [2]. We have been unable to contact the other authors regarding the retraction of their article.

Published online: 02 May 2017

\section{References}

1. Ko YG, Kim DH, Park SB, Kim SW, Do YJ, Kim H. Expression of Ski in the Follicles of eCG-primed Immature Hypophysectomized Rat. J Anim Sci Technol. 2012;v.54(3):151-6. http://dx.doi.org/10.5187/JAST.2012.54.3.151.

2. Kim H, Yamanouchi K, Nishihara M. Expression of ski in the granulosa cells of atretic follicles in the rat ovary. J Reprod Dev. 2006;52:715-21. 